\title{
HETEROSIS IN RED CLOVER
}

\author{
Rolf MANneR
}

Agricultural Research Centre, Department of Plant Breeding, Jokioinen

Received March 3, 1963

Red clover (Trifolium pratense L.) is one of the most important fodder crops in northern Europe. The importance of red clover in Finland is emphasized by PaAtela (10) and VAlLe (25). Extensive plant breeding work is carried out with red clover in northern Europe, i.e. in Denmark, Finland, Norway and Sweden (4). The characteristics of the red clover material grown in Finland are investigated by PAATELA (11). The plant breeding methods used in Finland for red clover are inter alia described by Pohjakallio $(13,14,15)$, Pohjakallio, Multamäki \& Nuorvala (16) and PaAtela (12).

Red clover is on the whole a cross-fertilizing plant, but several investigators have also found self-fertility in red clover. The self-fertility varies very much and in many cases it seems to be pseudofertility $(2,5,6,17,19,20,23,26,27,28)$. A more or less pronounced heterosis in red clover was noted in certain characters by Williams (29), Wexelsen (26), Salamov (18) and Lielmanis (7).

Bulk crossing of red clover for exploitation heterosis has been tried by SaLAMOV (18), Lielmanis (7) and Paatela (verbal information).

\section{Material and methods}

The present author found it of practical interest for plant breeding and plant husbandry to undertake experiments to explore the practical possibilities of making bulk crosses and mixtures between red clover strains, and of investigating the possibilities of obtaining practically usable strains of crosses by a breeding method for combining ability. The present investigation has been carried out at the Plant Breeding Institute Gullåker, Hammenhög, Sweden, in connection with the practical plant breeding work at the station. "Strain" = marketed variety, local strain or number variety. 
The following marketed strains are used in the present investigation as parents: the Swedish strains: Merkur, Monark, Essi, Lindby II, Resistenta, Silo, and Bara and the Danish strains Hinderupsgaard, Hjelm, ( tofte, and Daeno III. In addition a number of experimental strains in breeding work were also used in crosses. As space does not allow the describing of all the strains used in crosses, the author wishes to state that the material is representative of a broad Swedish and in some part Danish material in red clover. In addition, the author will endeavour to show that this is an average material of diploid red clover cultivated in the south of Sweden. The number of trials (comparisons) and crosses (combinations) is given in the tables. In the tables the yields are given for different harvest years, $" n$ " $=$ number of harvest seasons. Generally speaking it may be said that the number of crosses is rather large, but that the different crosses have undergone trials for only a short time. The latter is due to the fact that the yield experiments in red clover require much time and that unfortunately the time period has been limited.

The trials were carried out at the experimental farm Gullåker in the years $1951-58$. The plots have in all cases been $10 \mathrm{~m}^{2}$ and the number of replications have in most cases been $3-5$. The largest difference in flowering time has been 12 days between strains tried in the same experiment (Essi-Merkur) (8), in all other comparisons the differences have been smaller. The question has risen whether the differences in earliness have influenced the possibilities of comparing the earliest and latest developing strains with each other. The above mentioned strains have, however, been compared in a number experimental series $(1,3,21,22)$. In the governmental experimental programme SJF 210 the above strains are also compared in the same experiments. Such an experimental series has also been carried out at Gullåker in the years $1954-58$ (21). These trials have taken place in the same experimental fields as the experiments of the present study. The harvest has in the present study been taken in the same time as in the comparable governmental trials at Gullåker and the same methods have been used. The methods including the harvest time determination have consequently been officially approved. The harvest has been carried out when the first flowers have appeared in Merkur i.e. when the earlier strains have had a number of flowers. Reasons for the comparison of strains of different earliness in the same governmental experiments have been inter alia, that the red clover strains differ greatly, i.e., the earliness of the different plants in the same strain varies (24). Further it has been expected that the errors caused by the difference in earliness are smaller than the errors which would arise if the comparisons were undertaken in different experiments, or if different strains in the same experiment were harvested on different days. Further it is expected that the errors will be small or none if two harvests per season are taken. These arguments have also been accepted in the present investigation.

All possible measures were taken to avoid influence from the border effect. All weights refer to fresh green matter weighed immediately after harvest with an accuracy of 100 grams.

The seeds used for the experiments were received, in the case of the marketed strains, from the breeders. The crosses were produced by growing the strains in alternating rows or alternating plots. The seed was then harvested separately for 
the different crosses. The number of replications varied from 3 to about 20 in the seed cultivations, being in most cases $3-5$. As the parents had good normal fertility crosses between the strains grown together as well as within the strains occurred. The "hybrid seed" production was consequently not based on male sterile material. Two different types of shybrid seed» were produced, namely: 1. S e p a r a t e bulk crosses i.e. two or more strains are crossed together, but only the seed for the mother plots is included. For example, if the strains A and Bare crossed together the seed harvested is a mixture of about $50 \% \mathrm{~A} \times \mathrm{B}$ and $50 \% \mathrm{~A} \times \mathrm{A}$, and if three strains $\mathrm{A}, \mathrm{B}$ and $\mathrm{C}$ are crossed together the harvested seed will be a mixture of about $33.3 \% \mathrm{~A} \times \mathrm{B}, 33.3 \% \mathrm{~A} \times \mathrm{C}$ and $33.3 \% \mathrm{~A} \times \mathrm{A} .2$. R e ciproca 1 bulk crosses i.e. two or more strains are sown together either in different rows or the seed is mixed before sowing the seed cultivation. According to the above mentioned examples the seed harvested will be about $50 \% \mathrm{~A} \times \mathrm{B}, 25 \% \mathrm{~A} \times \mathrm{A}$ and $25 \% \mathrm{~B} \times \mathrm{B}$, if two strains are crossed together. If three strains are crossed together, the seed will be about $22.2 \% \mathrm{~A} \times \mathrm{B}, 22.2 \% \mathrm{~A} \times \mathrm{C}, 22.2 \% \mathrm{~B} \times \mathrm{C}$, $11.1 \% \mathrm{~A} \times \mathrm{A}, 11.1 \% \mathrm{~B} \times \mathrm{B}$ and $11.1 \% \mathrm{C} \times \mathrm{C}$.

Of the two forms of bulk crosses three different types of crosses have been investigated, namely, with 1 . two strains involved, 2. three strains involved and 3 . more than three strains involved.

The percentage of crosses obtained is discussed in an article on beets (9). In cases where two strains are grown in alternating rows the percentage of crosses will be \pm 50 , if no better fertility is to be found between different strains than within the strain and the earliness of the strains being about the same.

In many cases in the present investigation selection for persistence in the generation for seed cultivation was performed. This selection was a natural selection for persistence, performed in such a way that seed was taken in two - or three - year old seed cultivations established and treated in the same manner as earlier described, or plants were chosen from old plantations.

The mixtures of seed were made in the laboratory in such a manner that equal quantities of germinative seeds were mixed and the seed was sown in seed cultivations; the harvested seed from the seed cultivation was then used for green matter trials.

To obtain the largest possible opportunities for comparison, all values in the calculation were performed as \pm values in comparison with the check. The present paper does not give the names of the best crosses nor the names of the parents used in them, as these crosses may possibly be of commercial interest to my former employer Otto J. Olson \& Sons Ltd.

\section{Comparison between mother strains and progeny}

The first point considered in planning the present investigation was whether the bulk crosses have on an average better or worse yields than the parental strains? The parental strains are the best average strains grown in the area in which the experiments were conducted. 
In the present material a total of 36 crosses have been tested. On an average the bulk crosses gave larger green matter yields in all the four harvests investigated. Since the different bulk crosses are not very much tested it has not been possible to draw conclusions as to the performance of individual crosses.

Table 1. Comparisons between mother strains and progeny

\begin{tabular}{|c|c|c|c|c|c|c|c|c|c|}
\hline & \multirow{2}{*}{$\begin{array}{c}\text { Number } \\
\text { of combi- } \\
\text { nations }\end{array}$} & \multirow[b]{2}{*}{$\mathrm{n}$} & \multicolumn{3}{|c|}{ First harvest year } & \multicolumn{4}{|c|}{ Second harvest year } \\
\hline & & & $\begin{array}{c}\text { First } \\
\text { harvest }\end{array}$ & $\begin{array}{l}\text { Second } \\
\text { harvest }\end{array}$ & $\begin{array}{l}\text { Total } \\
\text { yield }\end{array}$ & $\mathbf{n}$ & $\begin{array}{c}\text { First } \\
\text { harvest }\end{array}$ & $\begin{array}{l}\text { Second } \\
\text { harvest }\end{array}$ & $\begin{array}{l}\text { Total } \\
\text { yield }\end{array}$ \\
\hline \multicolumn{10}{|l|}{ A 11 bulk crosses } \\
\hline Mothers & & 69 & & & & 44 & & & \\
\hline Kilograms per hectare & & & 28322 & 16016 & 44338 & & 20451 & 13429 & 33880 \\
\hline Relative value & & & 100 & 100 & 100 & & 100 & 100 & 100 \\
\hline Progeny & 36 & 69 & & & & 44 & & & \\
\hline Kilograms per hectare & & & 28886 & 17998 & 46884 & & 20747 & 13917 & 34664 \\
\hline Relative value & & & 102 & 112 & 106 & & 101 & 104 & 102 \\
\hline
\end{tabular}

Table 2. Crossings in which two strains are crossed together

\begin{tabular}{|c|c|c|c|c|c|c|c|c|c|}
\hline & \multirow{2}{*}{$\begin{array}{l}\text { Number } \\
\text { of combi- } \\
\text { nations }\end{array}$} & \multirow[b]{2}{*}{$\mathrm{n}$} & \multicolumn{4}{|c|}{ First harvest year } & \multicolumn{3}{|c|}{ Second harvest year } \\
\hline & & & $\begin{array}{c}\text { First } \\
\text { harvest }\end{array}$ & $\begin{array}{l}\text { Second } \\
\text { harvest }\end{array}$ & $\begin{array}{l}\text { Total } \\
\text { yield }\end{array}$ & n & $\begin{array}{c}\text { First } \\
\text { harvest }\end{array}$ & $\begin{array}{l}\text { Second } \\
\text { harvest }\end{array}$ & $\begin{array}{l}\text { Total } \\
\text { yield }\end{array}$ \\
\hline \multicolumn{10}{|l|}{ A $11 \mathrm{bu} 1 \mathrm{k}$ crosses } \\
\hline Parents & & 14 & & & & 14 & & & \\
\hline Kilograms per hectare & & & 28947 & 17428 & 46375 & & 22291 & 11622 & 33913 \\
\hline Relative value & & & 100 & 100 & 100 & & 100 & 100 & 100 \\
\hline Progeny & 8 & 14 & & & & 14 & & & \\
\hline Kilograms per hectare & & & 30231 & 17677 & 47908 & & 21995 & 12127 & 34122 \\
\hline Relative value & & & 104 & 101 & 103 & & 99 & 104 & 101 \\
\hline \multicolumn{10}{|c|}{ Separatebulk crosses } \\
\hline Parents & & 10 & & & & 10 & & & \\
\hline Kilograms per hectare & & & 27351 & 17545 & 44896 & & 22880 & 12748 & 35628 \\
\hline Relative value & & & 100 & 100 & 100 & & 100 & 100 & 100 \\
\hline Mothers & & 10 & & & & 10 & & & \\
\hline Kilograms per hectare & & & 28403 & 16069 & 44472 & & 22005 & 13418 & 35423 \\
\hline Relative value & & & 100 & 100 & 100 & & 100 & 100 & 100 \\
\hline Progeny & 4 & 10 & & & & 10 & & & \\
\hline Kilograms per hectare & & & 29939 & 17675 & 47614 & & 23155 & 13622 & 36777 \\
\hline Relative value (parental & mean) & & 109 & 101 & 106 & & 101 & 107 & 103 \\
\hline Relative value (mothers) & & & 105 & 110 & 107 & & 105 & 102 & 104 \\
\hline \multicolumn{10}{|c|}{ Reciprocalbulk crosses } \\
\hline Parents & & 4 & & & & 4 & & & \\
\hline Kilograms per hectare & & & 30439 & 19636 & 50075 & & 20816 & 11743 & 32559 \\
\hline Relative value & & & 100 & 100 & 100 & & 100 & 100 & 100 \\
\hline Progeny & 4 & 4 & & & & 4 & & & \\
\hline Kilograms per hectare & & & 30961 & 17683 & 48644 & & 19096 & 11185 & 30281 \\
\hline Relative value & & & 102 & 90 & 97 & & 92 & 95 & 93 \\
\hline
\end{tabular}


The reason for a larger number of comparisons in the first harvest year (Table 1) lies partly in the fact that a number of second year experiments were not harvested by the time the results were collected in to tables and partly in the fact that a number of second year experiments could not be harvested because the plants were killed by clover rot (Sclerotinia trifoliorum Eriks.).

\section{Dependence on number of strains crossed together}

In the present investigation an effort has been made to cross two, three or more strains together. The mean results are given in Table 2 (two strains crossed together), Table 3 (three strains crossed together) and Table 4 (several strains crossed together). The results show that no big differences are to be found between crosses in which 2 or 3 strains are crossed together if a comparison is made with the

Table 3. Crossings in which three strains are crossed together

\begin{tabular}{|c|c|c|c|c|c|c|c|c|}
\hline & \multirow{2}{*}{$\begin{array}{c}\text { Number } \\
\text { of combi- } \\
\text { nations }\end{array}$} & \multicolumn{4}{|c|}{ First harvest year } & \multicolumn{3}{|c|}{ Second harvest year } \\
\hline & & $\mathrm{n}$ & $\begin{array}{c}\text { First } \\
\text { harvest }\end{array}$ & $\begin{array}{l}\text { Second } \\
\text { harvest }\end{array}$ & $\begin{array}{l}\text { Total } \\
\text { yield }\end{array}$ & $\begin{array}{l}\text { n First } \\
\text { harvest }\end{array}$ & $\begin{array}{l}\text { Second } \\
\text { harvest }\end{array}$ & $\begin{array}{l}\text { Total } \\
\text { yield }\end{array}$ \\
\hline Parents & & 12 & & & & 9 & & \\
\hline Kilograms per hectare & & & 29321 & 17772 & 47093 & 24538 & 13444 & 37982 \\
\hline Relative value & & & 100 & 100 & 100 & 100 & 100 & 100 \\
\hline Mothers & & 12 & & & & 9 & & \\
\hline Kilograms per hectare & & & 29406 & 17987 & 47393 & 25182 & 13421 & 38603 \\
\hline Relative value & & & 100 & 100 & 100 & 100 & 100 & 100 \\
\hline Progeny & 4 & 12 & & & & 9 & & \\
\hline Kilograms per hectare & & & 30733 & 18749 & 49482 & 26103 & 13359 & 39462 \\
\hline Relative value (parenta & mean) & & 105 & 106 & 105 & 106 & 99 & 104 \\
\hline Relative value (mother & & & 105 & 104 & 104 & 104 & 100 & 102 \\
\hline
\end{tabular}

Table 4. Crossings in which many strains are crossed together

\begin{tabular}{|c|c|c|c|c|c|c|c|c|c|}
\hline & \multirow{2}{*}{$\begin{array}{c}\text { Number } \\
\text { of combi- } \\
\text { nations }\end{array}$} & \multicolumn{5}{|c|}{ First harvest year } & \multicolumn{3}{|c|}{ Second harvest year } \\
\hline & & $\mathrm{n}$ & $\begin{array}{c}\text { First } \\
\text { harvest }\end{array}$ & $\begin{array}{l}\text { Second } \\
\text { harvest }\end{array}$ & $\begin{array}{l}\text { Total } \\
\text { yield }\end{array}$ & $\mathbf{n}$ & $\begin{array}{c}\text { First } \\
\text { harvest }\end{array}$ & $\begin{array}{l}\text { Second } \\
\text { harvest }\end{array}$ & $\begin{array}{l}\text { Total } \\
\text { yield }\end{array}$ \\
\hline Parents & & 8 & \multicolumn{7}{|c|}{6} \\
\hline Kilograms per hectare & & & 27654 & 15427 & 43081 & $c$ & 19619 & 13462 & 33081 \\
\hline Relative value & & & 100 & 100 & 100 & & 100 & 100 & 100 \\
\hline Mothers & & 8 & \multicolumn{7}{|c|}{6} \\
\hline Kilograms per hectare & & & 27420 & 14908 & 42328 & & 19255 & 12828 & 32083 \\
\hline Relative value & & & 100 & 100 & 100 & & 100 & 100 & 100 \\
\hline Progeny & 4 & 8 & \multicolumn{7}{|c|}{6} \\
\hline Kilograms per hectare & & & 26483 & 15092 & 41575 & & 14346 & 12560 & 26906 \\
\hline Relative value (parenta & mean) & & 96 & 98 & 97 & & 73 & 93 & 81 \\
\hline Relative value (mother: & & & 97 & 101 & 98 & & 75 & 98 & 84 \\
\hline
\end{tabular}


parental mean, but if a comparison is made with the mothers, the bulk crosses, based on three strains, have shown results that are not as good as the bulk crosses based on only two strains. The result of this last mentioned comparison is furthermore in agreement with the results obtained with bulk crosses in which many strains were crossed together (Table 4). This table shows that the yields of the bulk crosses based on many strains have been considerably smaller in comparison with those of the parents than those of bulk crosses, which are based on only a few strains.

The yields in the second harvest year are much smaller - relatively - for the bulk crosses based on many strains than those based on only two or three strains.

\section{Comparisons between separate and reciprocal bulk crosses}

In Table 5 a comparison is given between separate and reciprocal bulk crosses. The number of combinations and trials was much larger for the separate bulk crosses. The separate bulk crosses have on an average given higher green matter yields than the means of the parents. The corresponding comparison for the reciprocal bulk crosses shows the average green matter yields for both harvest years to be smaller than for the parents.

Table 5. Comparison between separate and reciprocal bulk crosses.

\begin{tabular}{|c|c|c|c|c|c|c|c|c|c|}
\hline & \multirow{2}{*}{$\begin{array}{c}\text { Number } \\
\text { of combi- } \\
\text { nations }\end{array}$} & \multicolumn{5}{|c|}{ First harvest year } & \multicolumn{3}{|c|}{ Second harvest year } \\
\hline & & $\mathrm{n}$ & $\begin{array}{c}\text { First } \\
\text { harvest }\end{array}$ & $\begin{array}{l}\text { Second } \\
\text { harvest }\end{array}$ & $\begin{array}{l}\text { Total } \\
\text { yield }\end{array}$ & $\mathrm{n}$ & $\begin{array}{c}\text { First } \\
\text { harvest }\end{array}$ & $\begin{array}{l}\text { Second } \\
\text { harvest }\end{array}$ & $\begin{array}{l}\text { Total } \\
\text { yield }\end{array}$ \\
\hline \multicolumn{10}{|c|}{ Separatebulk crosses } \\
\hline Parents & & 62 & & & & 39 & & & \\
\hline Kilograms per hectare & & & 28256 & 16034 & 44290 & & 20592 & 13525 & 34117 \\
\hline Relative value & & & 100 & 100 & 100 & & 100 & 100 & 100 \\
\hline Progeny & 36 & 62 & & & & 39 & & & \\
\hline Kilograms per hectare & & & 28969 & 18252 & 47221 & & 21473 & 13985 & 35458 \\
\hline Relative value & & & 103 & 114 & 107 & & 104 & 103 & 104 \\
\hline Reciprocal bulk & crosses & & & & & & & & \\
\hline Parents & & 7 & & & & 5 & & & \\
\hline Kilograms per hectare & & & 28905 & 15852 & 44757 & & 19354 & 12682 & 32036 \\
\hline Relative value & & & 100 & 100 & 100 & & 100 & 100 & 100 \\
\hline Progeny & 3 & 7 & & & & 5 & & & \\
\hline Kilograms per hectare & & & 28151 & 15746 & 43897 & & 15090 & 13385 & 28475 \\
\hline Relative value & & & 97 & 99 & 98 & & 78 & 106 & 89 \\
\hline
\end{tabular}

The difference between the reciprocal and the separate bulk crosses is that the reciprocal bulk crosses are $\left(\mathrm{P}_{1}+\mathrm{P}_{2}\right)+\left(\mathrm{P}_{1} \rightleftharpoons \mathrm{P}_{2}\right)$, while the separate bulk crosses are $\mathrm{P}_{1}+\left(\mathrm{P}_{1} \times \mathrm{P}_{2}\right)$. The present author found at an early stage an indication that the separate bulk crosses would give the best practical results if the best strain the strain with the most desirable characteristics was used as mother strain. In this connection it must however be pointed out that the separate bulk crosses, not only 
in comparison with the parental mean (Table 5) but also in comparison with the mothers, have given higher green matter yields (Table 2).

\section{The influence of selection on bulk crosses}

From the results discussed above it appears that the bulk crosses have on an average given larger green matter yields than both the mothers and, on an average, the parents, if compared in every individual case. It is further indicated by the data given previously that the average performance is not as good in the second harvest year as in the first. The present author consequently came at an early stage to be interested in trying a selection for persistence parallel with the production of the

Table 6. Comparisons between parents and progeny at bulk crossing and selection

\begin{tabular}{|c|c|c|c|c|c|c|c|c|c|}
\hline & \multirow{2}{*}{$\begin{array}{l}\text { Number } \\
\text { of combi- } \\
\text { nations }\end{array}$} & \multicolumn{5}{|c|}{ First harvest year } & \multicolumn{3}{|c|}{ Second harvest year } \\
\hline & & $\mathbf{n}$ & $\begin{array}{c}\text { First } \\
\text { harvest }\end{array}$ & $\begin{array}{l}\text { Second } \\
\text { harvest }\end{array}$ & $\begin{array}{l}\text { Total } \\
\text { yield }\end{array}$ & $\mathbf{n}$ & $\begin{array}{c}\text { First } \\
\text { harvest }\end{array}$ & $\begin{array}{l}\text { Second } \\
\text { harvest }\end{array}$ & $\begin{array}{l}\text { Total } \\
\text { yield }\end{array}$ \\
\hline Parents & & 13 & \multicolumn{7}{|c|}{10} \\
\hline Kilograms per hectare & & & 26958 & 14812 & 41770 & & 18468 & 13607 & 32075 \\
\hline Relative value & & & 100 & 100 & 100 & & 100 & 100 & 100 \\
\hline Mothers & & 13 & \multicolumn{7}{|c|}{10} \\
\hline Kilograms per hectare & & & 27246 & 15125 & 42371 & & 18168 & 14190 & 32358 \\
\hline Relative value & & & 100 & 100 & 100 & & 100 & 100 & 100 \\
\hline Progeny & 5 & 13 & \multicolumn{7}{|c|}{10} \\
\hline Kilograms per hectare & & & 28349 & 18386 & 46735 & & 22350 & 14869 & 37219 \\
\hline Relative value (parenta & mean) & & 105 & 124 & 112 & & 121 & 109 & 116 \\
\hline Relative value (mothers & & & 104 & 122 & 110 & & 123 & 105 & 115 \\
\hline
\end{tabular}

seed of bulk crosses. The selection was carried out either in plantations or in sown stands. In the latter case three-year old sown stands were harvested for seed after natural selection. In planted stands selection was performed in the second or third year.

In Table 6 are given the average results of separate bulk crosses performed with selected plants of different strains.

\section{S u m mary}

The possibilities of utilizing heterosis in reciprocal and separate bulk crosses and through selection parallel with bulk crossing in red clover are discussed. The reciprocal bulk crosses have not reached the average green matter performance of the pure strains in the crosses. The performance in the second harvest year was on an average not as good as in the first harvest year. On an average, the separate bulk crosses have given higher green matter yields than both the mothers and the parental 
means. The yield performance was better - relatively — in the first harvest year than in the second harvest year in comparison with the mothers and with the parental means. If the bulk crosses are performed on plants selected for persistence the green matter yields have on an average been - relatively — higher than in other bulk crosses. The yields in the second harvest year have been comparatively better than in the first harvest year.

Acknowledgements. The present investigation has been carried out at the Gullåker Plant Breeding Institute, Hammenhög, Sweden, in the years 1949-58. My best thanks are due to my employer during the years $1949-58$, Otto J. Olson \& Sons AB and their late Managing Director Mr. Gottfrid Olson, B. Agr. My most sincere thanks are due to Professor Onni Pohjakallio, Dr. Agr. and Forestry, who has read the manuscript, to Mr. Erik Olsson and Miss Brigitte Bretschneider, who have helped me with the carrying out of the experiments, to my wife Mrs. Anita Manner, who has helped me with the calculations and treatment of the numerical material, and to Mr. C. Montagu Evans, M. A. (Cantab.) and Mr. Kalevi Multamäki, Dr. Agr. and Forestrg, for the linguistic revision.

\section{LITERATURE}

(1) Bengtsson, A. \& Larsson, N. G. 1958. Stamförsök med slåttervallväxter i södra Sverige under åren 1948-1957. K. lantbr. högsk. och stat. lantbr.förs. Stat. jordbr.förs. 112: 1-28.

(2) Fergus, E. N. 1922. Self-fertility in red clover. (A report of the progress in the attempt to secure self-fertile lines in red clover). Kentucky Agr. Exp. St. Circ. 29: 19-36.

(3) JuLÉN, G. 1951. Svalöfs Silo rödklöver - en ny klövertyp. Sveriges utsädesför. tidskr. $61: 347-355$.

(4) Julén, G. \& Åkerberg, E. 1951. Vallväxter. Svensk växtförädling 1: 423-506. Natur och Kultur, Stockholm.

(5) KIRK, L. E. 1925: Artifical self-pollination in red clover. Sci. Agr. 5: 179-189.

(6) - 1933. The progeny test and methods of breeding appropriate to certain species of crop plants. Amer. Nat. 67:515-531.

(7) Lielmanis, J. 1955. Clovers of the Latvian SSR. (Russ.). Zemledelie 1955: 52-55.

(8) MANNER, R. 1952. Några erfarenheter rörande återväxtförmågan hos våra vanligaste vallväxtarter och -stammar. Medd. Gullåkers växtförädlingsanst. 9-10: 219-224.

(9) - 1960. Studies in bulk crosses between some beet strains. J. Sci. Agric. Soc. Finl. 32: $199-210$.

(10) Paxtela, J. 1953. Maamme heinänurmien botaanisesta koostumuksesta. Suomen maatal.tiet. seur. julk. $79(3): 1-128$.

(11) - 1962. Characteristics of some diploid and tetraploid varieties of the late red clover Trifolium pratense v. subnudum subv. serotinum. Ibid. 99(4): 1-31.

(12) - - 1962. Viljelyskasvien alkuperä ja jalostaminen. Maanviljelysoppi 2: 1-33. PorvooHelsinki.

(13) Ронјakallio, O. 1938. Beiträge zu den züchtungstechnischen Untersuchungen bei der Veredlung des Rotklees. J. Sci. Agric. Soc. Finl. 10:67-77.

(14) - 1939. Kasvinjalostusbiologisia tutkimuksia apilamädästä. S. tiedeak. esit. ja pöytäk. 1939: 115-128. Ylipainos.

(15) - 1939. Untersuchungen über den Kleekrebs und seinen Anteil am Verschwinden des Klees in Kleegrasgemischen. Pflanzenbau 16: 136-160, 201-205.

(16) Pohjakallio, O. \& Multamäki, K. \& Nuorvala, S. 1937. Puna-apilan jalostusteknillisiä tutkimuksia. Referat: Veredlung des Rotklees. Züchtungstechnische Untersuchungen. Valt. maatal. koetoim. julk. 13: 1-66. 
(17) RenARd \& LAPPo, A. 1928. Beiträge zur Kenntnis der Biologie des Blühens von Rotklee (Trifolium pratense L.) verschiedener Herkunft. (Russ, with summary in English). Ann. der Weissruthen. Staatl. Akad. f. Landw. in Gorky. 6: 201-219.

(18) Salamov, A. 1953. Breeding research at the North Osetian State Breeding Station (Russ.). Selektsija i semenovodstvo 1953: 19-24.

(19) Schieblich, J. 1939: Selbstfertilität bei Rotklee (Trifolium pratense L.). Züchter 11: 89-90.

(20) Schlecht, F. 1922. Untersuchungen über die Befruchtungsverhältnisse bei Rotklee (Trifolium pratense). Z. f. Pfl. zücht. 8: 121-157.

(21) Statens Jordbruksförsök, 1954-59. SJF 210. Försöksplaner 1954-59. - (Mimeographed).

(22) Statens Jordbruksförsök 1956. Planer för Hushållningssällskapens lokala växtodlingsförsök år 1957. 1-57. Stockholm.

(23) Sylven, N. 1929. Om rödklöverns självfertilitet. Nord. jordbr. forsk. foren. 1929: 697-712.

(24) Umaerus, M. \& Åkerberg, E. 1959. Till frågan om typ- och stambeteckning hos rödklöver. Sv. utsädesf. tidskr. 69: 111-126 (With English summary).

(25) VAlle, O. 1957. The problem of red clover seed production in Finland. J. Sci. Agric. Soc. Finl. 29: $177-184$.

(26) WeXelsen, H. 1945. Studies on fertility, inbreeding and heterosis in red clover (Trifolium pratense L.). Skrift. Norske Vidensk.-Akad. Mat.Naturv. K1. Oslo 1: 1-141.

(27) Williams, R. D. 1925. Studies concerning the pollination, and breeding of red clover. Welsh Plant Breed. Sta. Bull. Ser. H. 4: 1-58.

(28) - -1931 . Self- and cross-sterility in red clover. Welsh Plant Breed. Sta. Bull. 12: $181-208$.

(29) - 1937. Heterosis in red clover. Effect of in-breeding in $F_{2}$ and $F_{3}$ populations. Welsh $J$. Agric. 13: 172-190.

\section{SELOSTUS:}

HETEROOSI PUNA-APILASSA

ROLF MANNER

Maatalouden tutkimuskeskus, Kasvinjalostuslaitos, Jokioinen

Vuosina $1950-56$ on Gullåkerin kasvinjalostuslaitoksella suoritettu puna-apilakantojen vălisiä risteytyksiä. Täten saatuja risteytymiä on kokeiltu kantakokeissa mainitun kasvinjalostuslaitoksen koekentillä vuosina $1951-58$. Näitä risteytymiä on verrattu vanhempiinsa. Yhteensä on kokeiltu 36 eri risteytysyhdistelmää. Risteytymät ovat keskimäärin antaneet suurempia tuorerehusatoja kuin vanhempansa. Parhaimmiksi näyttävät tuorerehusadot muodostuneen silloin, kun risteytymien siemen on otettu valioyksilöistä tai vanhasta nurmesta. Viimeksi mainitussa tapauksessa apilan kestävyyskin näyttää parantuneen huomattavasti. Se on nimittäin tällöin pystynyt antamaan suhteellisesti suurempia tuorerehusatoja toisena kuin ensimmäisenä satovuotena. 